\title{
Notes and Records of Little-Known Species of Birds from Puerto Rico ${ }^{1}$
}

\section{Francis J. Rolle ${ }^{2}$ \\ INTRODUCTION}

The purpose of this paper is to review the ornithological notes and records covering little-known species of birds from Puerto Rico, past and present, and to put them into one publication. For years much of this information has been scattered through a number of books, journals, and printed and unpublished notes. Many of these works are now out of print and others are scarce and difficult to obtain. Hence it seemed logical that the result would be of use to all students of West Indian ornithology if these bits of information could be bound together into one paper.

A number of birds that are considered in this report are endemic to the Island. In some cases there is the possibility that they have become extinct. Species that are now extinct, and have been for a number of years, will not be considered here, nor will birds known only from fossil records be included. Many sight records, some carrying more weight than others, are to be found throughout the literature, and a good number have been included in this paper. These, however, must be looked upon as hypothetical listings for lack of more valid information concerning the respective species.

The author has been in residence in Puerto Rico for the past 7 years and has devoted much of his time to studying the birds of the Island. He wishes gratefully to acknowledge the many informative hours spent in discussion with Dr. Virgilio Biaggi, Jr., who so willingly gave of his knowledge of the birds of the Island. Dr. Biaggi has made available to the author his manuscript on the Island birds which will soon be in print. According to data contained in this manuscript, the total number of birds now known from the Island is 236 species. These are broken down into: 108 resident, 79 migrants, and 49 of doubtful status.

In the following annotated list, there are a number of outstanding records. A few of these are represented by skins in the avian collection of the Department of Biology, University of Puerto Rico, Mayagüez, P.R. Others are deposited in museums of much larger status throughout the New World and in Europe.

1 Contribution of the Institute of Caribbean Studies, University of Puerto Rico, Mayagüez, P.R.

2 Assistant Instructor, Biology Department, University of Puerto Rico, Mayagüez, P.R. 


\section{ANNOTATED LIST}

\section{Puffinus griseus (Gmelin), Sooty Shearwater}

This bird has never before been reported from Puerto Rico. Donald S. Erdman, Fishery Biologist for the Insular Fish and Game Division, listed two sight records in the log of his schooner, "May 29, 1954 at 4 p.m., dusky brown bird, black bill with a bent tip, 4 miles south of Guánica, P.R." Another record reads, "October 17, 1959, one gull-sized brown shearwater at 10:15 a.m., about 10 miles south of Parguera, P.R."

\section{Phaëthon aethereus mesonauta Peters, Red-billed Tropic Bird}

Wetmore $(15)^{3}$ mentioned that Cory published notes on various site records for this bird in 1888. He received his information from Taylor who, no doubt, erroneously identified the yellow-billed species as this one. There appear to be no other listings from the Island.

\section{Sula dactylatra dactylatra Lesson, Blue-faced Booby}

McCandless (13) had sight records off of Desecheo Island, P.R.

\section{Phalacrocorax olivaceus mexicanus (Brandt), Olivaceous Cormorant}

Danforth (8) sighted this bird at Cartagena Lagoon, P.R., on October 17, 1924. He did not collect it.

\section{Ardea occidentalis occidentalis Audubon, Great White Heron}

Wetmore (15) said that Gundlach reported seeing one specimen at Guánica Lagoon, P.R., in November 1873. There are no other reports from the Island.

\section{Dichromanassa rufescens colorata Griscom, Reddish Egrel}

One male was collected along with one female from the Cartagena Lagoon, P.R., by Jose A. Ramos on August 23, 1943. Both skins are in the avian collection in Mayagüez and bear catalog Nos. 136 and 137, respectively. The writer saw one individual in a swampy area near the Río Culebrinas, Columbus Park, Aguadilla, P.R., on September 9, 1956. It was not collected.

Botarus lentiginosus (Rackett), American Bittern

Apparently a migrant straggler to Puerto Rico. Wetmore (15) said that Gundlach saw it at Guánica Lagoon, P.R., in November 1873, and recorded a skin in Blanco's collection. On September 23, 1921 Struthers shot one in a mangrove thicket that was situated just south of Boquerón. Danforth (8) reported a sight record from Cartagena Lagoon, P.R., on Novem-

3 Italic numbers in parentheses refer to Literature Cited p. 340-1. 
ber 30, 1923. Barnés (4) reported on one taken (female, No. 855) near Añasco, P.R., by Mr. Luis Santos on November 14, 1947. This bird is now in the avian collection in Mayagüez.

\section{Eudocinus albus (Linnaeus), White Ibis}

Wetmore (15) mentioned a mounted specimen seen by a Dr. Richmond about 1900, in the avian collection owned by Dr. Agustín Stahl. There are bone fragments known from the Island, (Bond, 7).

\section{Ajaia ajaja (Linnaeus), Roseate Spoonbill}

McCandless (13) mentioned vague sight records from the Island as well as a sight record at sea north of Puerto Rico. Biaggi (5) also listed hypothetical records.

\section{Phoenicopterus ruber (Linnaeus), Flamingo}

Wetmore (15) mentioned early sight records by Gundlach, Ledru, and Hans West. It appears that the last resident bird was killed on Vieques Island, P.R., in 1940. It has since been introduced to Magüeyes Island, Parguera, P.R., and also at El Comandante race track, in Río Piedras, P.R.

\section{Olor columbianus (Ord), Whistling Swan}

Barnés ( 8 ) mentioned one collected at Guánica Lagoon, P.R., by Rafael Rivera Esbri on December 16, 1944. The skin was greatly damaged by insects before it could be taken care of and only the head was preserved.

\section{Chen hyperborea hyperborea (Pallas), Snow Goose}

Wetmore (15) mentioned that a number of reports were given to Gundlach. McCandless (13) reported the snow goose as a casual winter visitant.

Dendrocygna viduata (Linnaeus), Tree Duck

Biaggi (5) said that there is no direct evidence to show that this duck has ever been recorded from the Island. It appears that bone deposits, as listed by Wetmore, being found in Puerto Rico, were those pertaining to another species of tree duck. Bond (7) published a correction of this error.

Dendrocygna autumnalis discolor (Linnaeus), Black-bellied Tree Duck

This duck is possibly a vagrant straggler to the Island. There are no recent records. McCandless (18) called it a, "dubious former resident."

\section{Dendrocygna bicolor helva (Vieillot), Fulvous Tree Duck}

The fulvous tree duck was recorded by Biaggi and Rolle (6) in 1960, as the first record of this duck from the Island. A specimen is in the avian collection in Mayagüez. 
Anas platyrhynchus platyrhynchus (Linnaeus), Mallard

Biaggi (5) stated that three specimens had been collected from the Island, but none was preserved for record. McCandless (13) stated that this duck is a casual winter visitant.

Anas rubripes Brewster, Black Duck

Biaggi (5) stated that one was taken at Guánica Lagoon, P.R., by Saurille de Ponce. The location of the specimen is unknown. McCandless (13) called this duck a casual winter visitant.

\section{Anas bahamensis bahamensis (Iinnaeus), Bahama Pintail}

This duck is a very scarce resident. McCandless (13) stated that, "Experienced Puerto Rican hunters have never seen this duck." The writer has a number of sight records from Cartagena Lagoon, P.R., taken in November 1958. There are three skins in the avian collection in Mayagüez. These are: A male, No. 183, Cartagena Lagoon, P.R., March 18, 1941, V. Biaggi; unsexed skin, No. 211, Anegado Lagoon, P.R., January 14, 1942, J. Ramos; and a male, No. 876, Anegado Lagoon, P.R., January 1942, J. Ramos. Danforth (12) found this duck to be more common in the small islands east of Puerto Rico proper.

\section{Mareca penelope (Linnaeus), European Widgeon}

McCandless (13) listed a sight record from Cartagena Lagoon, P.R., for February 22, 1958.

\section{Oxyura dominca (Linnaeus), Masked Duck}

This duck is a very rare resident. Barnés (S) said, "The Masked Duck has been considered exceedingly rare in Puerto Rico and very few skins of this species have been collected." Wetmore (15) noted that Gundlach saw skins in the Stahl collection and also in the collections of Hjalmarson and Blanco. Danforth (12) thought this duck to be of only accidental occurrence in Puerto Rico. There are four skins in the avian collection in Mayagüez. These are: A male, No. 170, Anegado Lagoon, P.R., January 30, 1944, V. Biaggi; a male, No. 171, Añasco, P.R., October 21, 1943, J. Ramos; a female, No. 172, Guánica Lagoon, P.R., February 12, 1943, J. Ramos; and a male, No. 875, Guánica Lagoon, P.R., January 27, 1946, J. Ramos.

Aythya collaris (Donovan), Ring-necked Duck,

Wetmore (15) stated that Gundlach spoke of a specimen taken in 1873 from the Island. 


\section{Lophodytes cucullatus Linnaeus, Hooded Merganser}

Recorded by Biaggi and Rolle (6) in 1960 as the first record of this duck from the Island. One specimen in avian collection in Mayagüez.

\section{Mergus serrator serrator (Linnaeus), Red-breasted Merganser}

A specimen known to be from the Island, and collected by Barnés (1) is now in the avian collection in Mayagüez and bears the catalog No. 879 . This bird was erroneously identified as Mergus merganser americanus in the original published record, but has since been corrected in print by Bond ( 7$)$.

\section{Bucephala albeola (Linneaus), Bufflehead}

Wetmore (15) stated that, in 1900 , a Dr. Richmond found a mounted bird of this species in a collection in San Juan, P.R. The bird was supposed to have been collected by Agustín Stahl.

\section{Buteo platypterus brunnescens Danforth and Smyth, Puerto Rican} Broad-winged Hawle

A very rare endemic subspecies on the Island. Wetmore (15) mentioned that Gundlach claimed to have taken specimens. There are sight records by Danforth, Biaggi, and Ramos. The hawk is known to science only from the type specimen: A female, El Yunque Mountain, P.R., August 2, 1935, J. Adgar Smyth. The type is now in the U.S. National Museum in Washington, D.C. and bears catalog No. 359258.

Accipiter striatus venator (Wetmore), Puerto Rican Sharp-skinned Hawk

A very rare and local endemic subspecies in Puerto Rico. Biaggi (5) stated that the bird was first discovered in 1930. Wetmore (15) found it restricted to a small area in Maricao, P.R. The writer has seen this hawk only once, on April 21, 1957, on Monte del Estado, near Maricao, P.R.

\section{Aramus guarauna elucus Peters, Limpkin}

Bond $(\gamma)$ stated, "Now possibly extirpated in P.R." There have been many sight records through the years but all have been found to pertain to the young of Nycticorax nycticorax hoactli. Wetmore (15) mentioned two skins now in the U.S. National Museum, that were taken by Latimer in the 1890 's.

Laterallus jamaicensis (Gmelin), Black Rail

Wetmore (15) stated that Stahl reported collecting four black rail and Richmond claimed to have seen one of them. Danforth $(8,12)$ reported sight records from Guánica and Cartagena Lagoons, P.R. 


\section{Limosa haemastica Linnaeus, Hudsonian Godwit}

The only sight record from the Island was made on October 9, 1960 at Cartagena Lagoon, P.R., by a bird-census group led by Dr. James B. McCandless.

\section{Larus argentatus smithsonianus Coues, Herring Gull}

MeCandless (13) who mentioned sight records from Cartagena Lagoon, P.R., claimed that this gull is a sporadic visitant which comes to the Island mostly in spring.

\section{Amazona vittata vittata (Boddaert) Puerto Rican Parrot}

The Puerto Rican parrot is a rare endemic species in Puerto Rico. A small flock of about 200 birds remains on an insular reserve in the Luquillo mountains. Formerly common and widespread. Wetmore (15) found it restricted to mangrove swamps near Mameyes, on the eastern slopes of El Yunque, and in the forested regions near Utuado and Arecibo, P.R. There is only one skin in the avian collection in Mayagüez. The collector and sex are not indicated on the label. It was taken at El Yunque, on November 12, 1944, and bears the catalog No. 924 .

\section{Coccyzus erythropthalmus (Wilson), Black-billed Cuckoo}

Wetmore (15) mentioned that Gundlach saw a drawing of a black-billed cuckoo in Bello's album on the Puerto Rican avifauna. Bello had received the specimen, from which he drew the picture, from the interior of the Island.

\section{Asio flammeus portoricensis Ridgway, Puerto Rican Short-eared Owl}

This owl is a very rare and local endemic. McCandless (13) and Rolle (14) state that it was nearly exterminated on the Island, probably by the mongoose, Herpestes auropunctatus auropunctatus. Wetmore (15) saw it at Anegado Lagoon, P.R. There are many skins in various museums throughout the world. There are five skins in the avian collection in Mayagüez.

\section{Archelochus colubris (Linnaeus), Ruby-throated Hummingbird}

Bond (7) said that this bird is of doubtful occurrence on the Island. Wetmore (15) spoke of a drawing of one in Bello's album on Island birds.

Orthorhyncus cristatus exilis (Gmelin), Antillean Crested Hummingbird

This is a Lesser Antillean form that is well established on Vieques Island, P.R It has been seen but a few times on Puerto Rico proper. Wetmore (15) recorded it from eastern Puerto Rico. Bond ( $(7)$ says, it is "..... of doubt- 
ful occurrence in Puerto Rico." McCandless (13) claimed it was fairly common near Fajardo and Danforth (11) saw it on Vieques, P.R., in 1924.

Tyrannus tyrannus (Linnaeus), Eastern Kingbird

This bird has been mentioned in the literature by Hartlaub and Cory. There are no other references to it from Puerto Rico.

Iridoprocne bicolor (Vieillot), Tree Swallow

Danforth reported seeing this swallow in Mayagüez, P.R., and Wetmore (15) stated that Gundlach saw a drawing of the tree swallow in Bello's album.

\section{Corvus leucognaphalus Daudin, White-necked Crow}

This rare resident is probably extinct today, since there have been no valid reports of it from the Island since the San Felipe hurricane of 1928. The author considers the 1952 and 1958 sightings as dubious records.

Hylocichla mustelina (Gmelin), Wood Thrush

Wetmore (15) said that Gundlach saw a drawing of this thrush in Bello's album.

\section{Parulidae (Wood Warblers)}

There are numerous sight records from the Island of the wood warblers. Of the 20 or so that have been recorded from Puerto Rico only about 12 are considered by the author to be valid records. Species that should be placed on a hypothetical list are: Protonotaria citrea (Boddaert), prothonotary warbler; Helmintheros vermivorus (Gmelin), worm-eating warbler; Dendroica castanea (Wilson), bay-breasted warbler; Oporornis formosus (Wilson), Kentucky warbler; Oporornis agilis (Wilson), Connecticut warbler; Oporornis philadelphia (Wilson), mourning warbler, and Wilsonia canadensis (Linnaeus), Canada warbler.

\section{Molothrus bonariensis minimus Dalmas, Glossy Cowbird}

This is a recent arrival in the Lesser Antilles. McCandless (19) called it, "an irregular winter visitant to eastern Puerto Rico, Culebra and Vieques Islands," Bond (7) said it was, "of accidental occurrence on Vieques Island (about 1860) off of Puerto Rico." Grayce $(A u k, 1957)$ saw a flock of from 150 to 175 , at Cabo Rojo, P.R., January 2, 1956.

\section{Piranga olivacea (Gmelin), Scarlet Tanager}

Barnés (3) collected a specimen of the scarlet tanager on Mona Island, P.R., in May 1944. The skin is now in the avian collection in Mayagüez and bears catalog No. 1012 . 
Guiraca caerulea caerulae (Linnaeus), Blue Grosbeak

One blue grosbeak was collected on Mona Island, P.R. by Kuns.

\section{Passerina cyanea (Linnaeus), Indigo Bunting}

McCandless (13) mentioned sight records of the indigo bunting from Cartagena Lagoon, P.R. on February 5, 1955 and April 6, 1957. He also mentioned a sight record from Río Piedras, P.R.

\section{Melospiza lincolnii lincolnii (Audubon), Lincoln's Sparrow}

Danforth (9) reported seeing a Lincoln's sparrow on a brushpile near La Plata, P.R., December 14, 1923.

\section{SUMMARY}

Notes and records of little-known species of birds from Puerto Rico are presented in an annotated list form. In some cases the records represent migrant birds never before reported from the Island. The bulk of the data was gleaned from past publications, a number of which are now out of print and not available to those seeking information.

\section{RESUMEN}

Se presentan en forma anotada algunas notas y citas de especies poco conocidas de las aves de Puerto Rico. En algunos casos representan especies migratorias que nunca han sido citadas de la Isla. La mayor parte de esta información se obtuvo de publicaciones anteriores, algunas de las cuales están agotadas.

\section{LITERATURE CITED}

1. Barnés, V., Jr., American Merganser in Puerto Rico, Auk 62 460, 1945.

2. - The birds of Mona Island, Puerto Rico, Auk 63 327, 1946.

3. - Additions to the Puerto Rican avifauna, $A u k 64400-6,1947$.

4. - American Bittern in Puerto Rico, Auk 65 115, 1948.

5. Biaggi, V., Jr., The birds of Puerto Rico, unpublished manuscript.

6. Biaggi, V., Jr., and F. J. Rolle, Records of two migrant waterfowl for Puerto Rico, $A u k .78$ 425, 1961.

7. Bond, J., Check-List of the Birds of the West Indies, The Academy of Natural Sciences of Philadelphia, pp. 1-214, plus supplements.

8. Danforth, S. T., Birds of the Cartagena Lagoon, Porto Rico, J. Agr. Univ. P.R., 10 1-136, 1925.

9. - Puerto Rican ornithological records, J. Dept. Agr. P.R. 16 pp. 38, 44, 47, 70, 73, 84, 96, 103, 1931.

10. - The Puerto Rican form of the broad-winged hawk, J. Agr. Univ. P.R. 19 485-6, 1935.

11. - Ornithological investigations in Vieques Island, Puerto Rico, during December, 1935, J. Agr. Univ. P.R. 21 545, 549, 1937. 
12. - Los Pájaros de Puerto Rico, Rand McNally and Co., New York, N.Y., and Chicago, Ill., pp. 1-198, 1937.

13. McCandless, J. B., A Field Guide to the Birds of Puerto Rico, Inter-American University Press, San German, P.R., pp. 1-68, 1958.

14. Rolle, F. J., The Puerto Rican short-eared owl, Fla. Nat. 33 75-7, 1960.

15. Wetmore, A., The birds of Puerto Rico and Virgin Islands, Sci. Surv. Porto Rico and Virgin Islands, 9 243-598, 1927. 